\title{
Exploring the business of urology: Strategy and strategic planning
}

Darren Beiko, MD, MBA, FRCSC; ${ }^{1}$ Elspeth Murray, MBA, PhD; ${ }^{2}$ Timothy O. Davies, MD, FRCSC; ${ }^{3}$ J. Stuart Oake, MD, MBA, FRCSC; ${ }^{4}$ Anne-Marie Houle, MD, MBA, FRCSC $^{5}$

${ }^{1}$ Department of Urology, Queen's University Kingston, ON; ${ }^{2}$ Smith School of Business, Queen's University, Kingston, ON; ${ }^{3}$ Department of Surgery, Division of Urology, McMaster University, Hamilton, ON; ${ }^{4}$ Department of Surgery, Division of Urology, University of Ottawa, Ottawa, ON; ${ }^{5}$ Department of Surgery, Division of Pediatric Urology, Université de Montréal, Montreal, QC; Canada

Cite as: Can Urol Assoc J 2017 Dec. 14; Epub ahead of print. http://dx.doi.org/10.5489/cuaj.5083

Published online December 14, 2017

$* * *$

According to the Oxford University Press, strategy is defined as a plan of action designed to achieve a long-term or overall aim. ${ }^{1}$ Why is strategy of importance to urologists? Many urologists end up in formal administrative leadership roles, yet most receive little or no formal education or training on strategy and how to develop and execute a strategic plan. In these leadership roles, urologists and other physicians are often required to aid in the development of strategic plan or at least action plans designed to achieve long-term goals. For example, urologists may become involved in the development of strategic plans for their regional urology program, their own department or division of urology/surgery, or may become involved in their hospital's, university's and/or School of Medicine's strategic planning process in some capacity. There are several additional examples of situations urologists may face that require an understanding of strategy and its implementation, including the building of a new clinic or clinical institute, the opening of a new surgical suite or a standalone surgical centre, the building of a new research centre, the opening of a new residency or fellowship program, or - of current interest to academic urologists - the initiation of a new educational program such as the Royal College of Physicians and Surgeons of Canada's Competence By Design (CBD) competency-based medical education (CBME) initiative. The objective of this article is to introduce urologists to the basic concepts of strategy and key components and steps in the strategic planning process so they are prepared when called upon to lead strategic initiatives or become involved in a strategic planning process. 


\section{Elements of a strategic plan}

The early stages of the strategic planning process focus on formulation of the strategic plan, whereas the late stages focus on implementation in order to achieve the objectives of the strategic plan. Various outlines of the elements of strategic plans have been described, and one sample outline is presented in Box $1 .^{2}$

\section{Overview of the strategic planning process}

The strategic planning process starts with gathering input from key stakeholders through meetings, interviews, surveys, storyboarding exercises or any combination thereof. The goal is to ensure that all relevant issues within the organization are captured so the strategic plan doesn't miss the target. Based on the input, the strategic framework-the mission, vision, values and strategic priorities - are defined and communicated.

Communication to key stakeholders, particularly the people who keep the engines of the organization running day to day, is important throughout the process, but especially at key points. Strategic priorities arise from the strategic framework and lay the foundation for the implementation plan through action plans for each strategic priority's objectives. The most responsible person and timelines generally accompany each action plan so each milestone can be tracked and followed through on to ensure success of the strategic plan. After implementation, formal review of the plans, objectives and strategies is necessary to allow any necessary adjustments. Solid strategic plans incorporate ongoing fluid reviews mid-implementation to ensure quick adjustments where appropriate. An example of a typical strategic planning process is shown in Figure 1.

\section{Strategic framework: mission, vision and values}

Central to any organization's strategic planning process is the development and communication of its strategic framework. This includes the organization's mission statement, vision, value proposition and core values. The mission speaks to the ongoing daily and weekly function and purpose of the organization, whereas the vision refers to a bigger picture evaluation of where the organization wants to go and what it strives to be. ${ }^{3}$ There is evidence in the strategy literature that a complete and high quality mission statement has a significantly positive effect on an organization's financial performance. ${ }^{5}$ Mission and vision statements can vary in length. In its 5-year 2014-2019 strategic plan, the Canadian Urological Association's vision was as follows: The CUA exists to promote the highest standard of urologic care for Canadians and to advance the science of urology. ${ }^{6}$ Some other examples of mission and vision statements of well-known medical organizations are shown in Table $1 .^{7-10}$ An organization's value proposition is a crucial component of its strategy because it is one of the key elements of the strategic triangle. ${ }^{4}$ In simple terms, a value proposition refers to what the organization does - the value it provides - and why it will be successful in providing that value. It may be that as part of the strategic planning process, the value proposition needs to be modified. 


\section{PEST and SWOT analyses}

During the strategic planning process, identification of the key internal (micro environment level) forces and major external (macro environment level) forces affecting the organization is done through SWOT (strengths, weaknesses, opportunities, threats) ${ }^{11}$ and PEST (political, economic, social and technological factors or trends) ${ }^{12}$ analyses, respectively. These micro environment and macro environment level forces can create threats and opportunities for an organization that may have an impact on its activities, performance and sustainability.

The goals of a SWOT analysis are to assess the micro environment forces acting upon an organization, including its strengths, weaknesses, market opportunities and potential threats. A SWOT analysis helps the organization identify significant factors that may impact its success. An example of what a SWOT analysis could look like for a typical urology department or division is shown in Figure 2.

The goals of a PEST analysis are to identify and address any current or future important external forces, factors, trends, opportunities and threats that are outside the control of the organization but may significantly impact an organization. A sample PEST analysis for a typical urology department or division is shown in Figure 3. SWOT and PEST analyses can be readily performed for almost any type of urological group practice in a small town community setting, large city non-academic setting or academic environment. The ultimate goal of these 2 analyses, is to identify the critical 'make-orbreak' issues and opportunities for the organization, solutions to which will inform any changes required to the mission, vision, value proposition and core values of the organization. These solutions are then expressed as strategic priorities in any strategic plan.

\section{Assimilation of the strategic plan}

After the environmental scan is complete, the organization starts pulling the strategic plan together. This process includes risk analysis and development of concrete strategic priorities or objectives. An example of a set of strategic priorities for a typical urology department or division is shown in Figure 4. There are usually a small manageable number of strategic priorities (i.e. 3-6 strategic priorities for most organizations), and each strategic priority usually has a small number of goals (i.e. 1-6 goals for each strategic priority) to be achieved through actions plans. For example, the Canadian Urological Association communicated the following four strategic priorities in its 5-year 2014-2019 strategic plan: ${ }^{16}$

- Increase Member Engagement

- $\quad$ Be the Voice of Urology in Public and Health Policy

- Become the Pre-eminent Urological Resource for Patients and Health Professionals

- Ensure the Financial Stability of the CUA 
In this example, each of the CUA's four strategic priorities would have accompanying action plans designed with appropriate timelines to meet each of the strategic priority's objectives, and one or two individuals (in this example, likely members of the CUA executive) would be nominated as the most responsible person(s) to be accountable for the successful completion of each action plan.

\section{The balanced scorecard}

Kaplan and Norton published the initial concept of the balanced scorecard in their landmark article published in the Harvard Business Review ${ }^{13}$ and later popularized the concept in a follow-up article titled Using the Balanced Scorecard as a strategic management system. ${ }^{14}$ The purpose of the balanced scorecard is to focus the organization on key performance metrics that will facilitate successful implementation of its strategic plan. The four interrelated elements of the balanced scorecard are: 1 . the internal business processes; 2. the customer; 3 . the financials; 4 . learning and growth. These four elements are shown in a sample format of a balanced scorecard as published by Kaplan and Norton in Figure $5 .{ }^{15}$ The balanced scorecard provides a process by which an organization could avoid focusing solely on the short-term financial metrics. Winning organizations were usually successful in tightly linking their strategic priorities and action plans with the four elements of the balanced scorecard, which in turn allows the organizations to monitor whether or not the strategic plan is achieving its intended outcomes. Figure 6 illustrates an example of a balanced scorecard for a potential urology department or division. In this balanced scorecard example, three indicators for each element are shown, and indicators would be connected to the organization's strategy map as shown in Figure 7 for an operational efficiency that results in decreased costs to the healthcare system.

\section{Personal strategic planning}

In general, strategic plans are most commonly used for an organization's corporate strategy. But urologists may consider employing a strategic plan for an individual strategic initiative or for their own career strategy. Personal strategic planning for professionals can be a productive exercise to grow personally and professionally. ${ }^{17,18}$

\section{Conclusions}

During their careers, many urologists will find themselves in leadership positions where they are called upon to develop a strategy or become involved in creating a strategic plan. Some urologists may even be required to lead a strategic planning process. This skill set is not familiar to all urologists because many receive little to no formal education or training on strategy and strategic planning. In addition to formal education or training, there are several decent books on strategy that may of interest to urologists, and some are listed in Table 2. Through the application of a simple approach to strategy and developing a strategic plan, urologists may turn a challenging situation into a rewarding one as their organization evolves. 


\section{References}

1. The Oxford Dictionaries. https://en.oxforddictionaries.com/definition/strategy. Oxford University Press. accessed August 18, 2017.

2. Richardson PR. Role of the General Manager MBUS 800 Course Slides, Queen's School of Business: Kingston, ON, August 2011.

3. Spallina JM. Strategic planning--getting started: mission, vision and values. $J$ Oncol Manag 2004;13:10-1.

4. Moore M and Khagram S. 2004. On Creating Public Value: What Business Might Learn from Government about Strategic Management. Corporate Social

Responsibility Initiative Working Paper No. 3. Cambridge, MA: John F. Kennedy School of Government, Harvard University.

5. Green Jr KW, Medlin B. The strategic planning process: the link between mission statement and performance. Acad Strat Manag J 2003;2:23-32.

6. About CUA | CUA - Canadian Urological Association. http://www.cua.org/en/about-cua, accessed September 7, 2017.

7. American Urological Association - Mission \& Vision. http://www.auanet.org/about-us/about-aua/mission-and-vision, accessed September 7, 2017.

8. The Royal College of Physicians and Surgeons of Canada: About the Royal College. http://www.royalcollege.ca/rcsite/about/about-royal-college-e, accessed September 7, 2017.

9. CMA: History, mission, vision, values. https://www.cma.ca/En/Pages/historymission-vision.aspx, accessed September 7, 2017.

10. CMPA - 2015-2019 Strategic Plan. https://www.cmpa-acpm.ca/en/about/whatwe-do/strategic-plan, accessed September 7, 2017.

11. Allio RJ. Strategic thinking: the ten big ideas. Strat Ldrshp 2006;34:4-13.

12. Thomas $\mathrm{H}$. An analysis of the environment and competitive dynamics of management education. J Manag Develop 2007;26:9-21.

13. Kaplan RS, Norton DP. The Balanced Scorecard: measures that drive performance. Harv Bus Rev 1992;70:71-9.

14. Kaplan RS, Norton DP. Using the Balanced Scorecard as a strategic management system. Harv Bus Rev 1996;74:75-85.

15. Kaplan RS, Norton DP. The balanced scorecard: translating strategy into action. Harvard Business School Press, Boston, MA; 1996.

16. Oake JS. Our strategy moving forward. Can Urol Assoc J 2015;9:11.

17. Morrisey GL. Creating Your Future: Personal Strategic Planning for Professionals. Berrett-Koehler Publishers, San Francisco, CA; 1992.

18. Garcia EV. Strategic planning: a tool for personal and career growth. Heart Asia 2016;8:36-9. 
Figures and Tables

Box 1. Sample strategic plan outline (adapted from Richardson ${ }^{2}$ )

- Strategic framework - vision, mission, values and objectives

- Identification of major clients and markets

- Positioning statement

- KPI scorecard

- Strategies/action plans to achieve objectives

- PEST analysis

- SWOT analysis

- Requirements from other business units

- Summary of major programs/projects

- Summary of anticipated human resource requirements

- Summary of financial impact and outcomes

KPI: key performance indicator; PEST: political, environmental, social, technological; SWOT: strengths, weaknesses, opportunities, threats

Fig. 1. Overview of the strategic planning process.

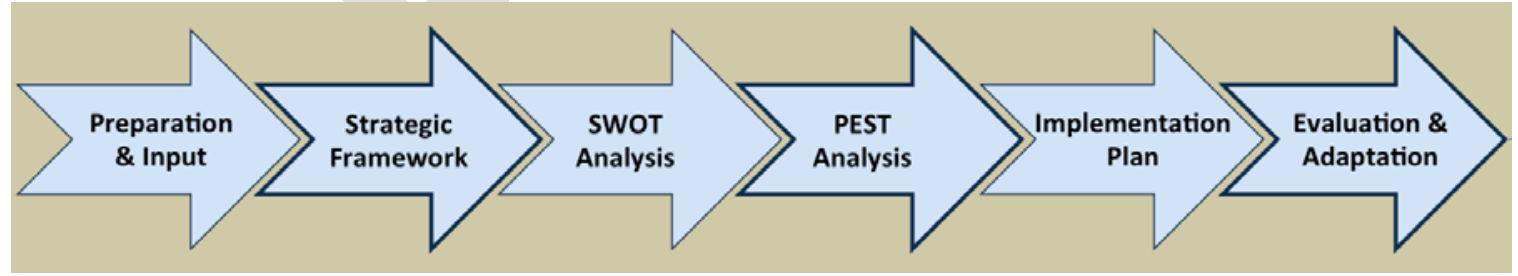


Fig. 2. Sample SWOT analysis for a urology division or department.

\section{S TRENGTHS}

Team characteristics that give it an advantage over competitors

- Timely access to care

- Quality of patient care

- Scholarly projects

- New robotics program

\section{OPPORTUNITIES}

External chances to make greater advances in the field of urology

- Fundraising partnerships

- New education programs

- Expansion of services outside the main hospital

\section{WEAKNESSES}

Team characteristics that place it at a disadvantage relative to others

- Gaps in technology

- Poor fundraising

- Decreased morale from long work hours

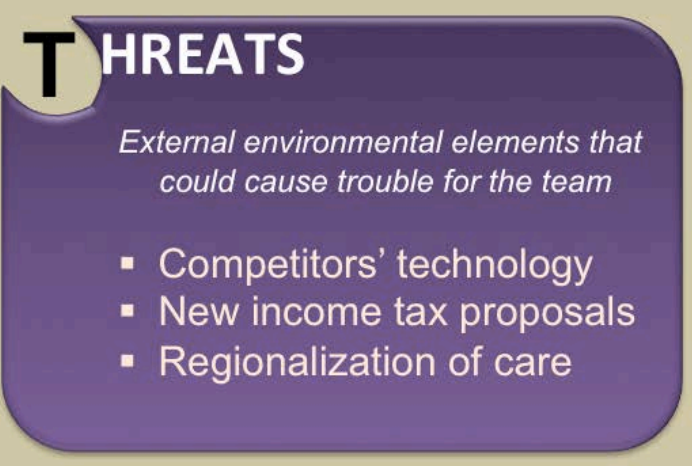


Fig. 3. Sample PEST analysis for a urology division or department.

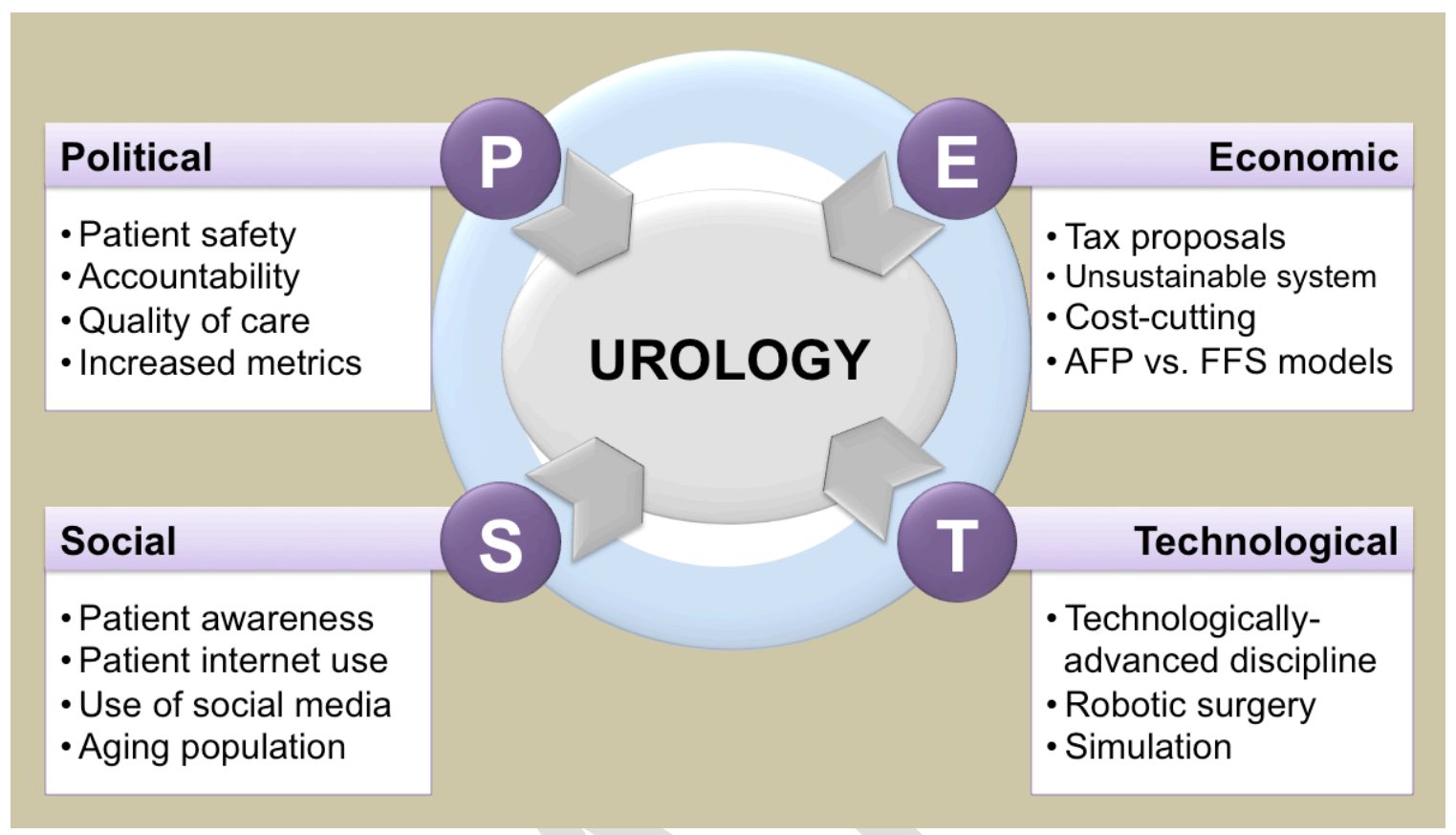

Fig. 4. Sample strategic objectives for a urology division or department.

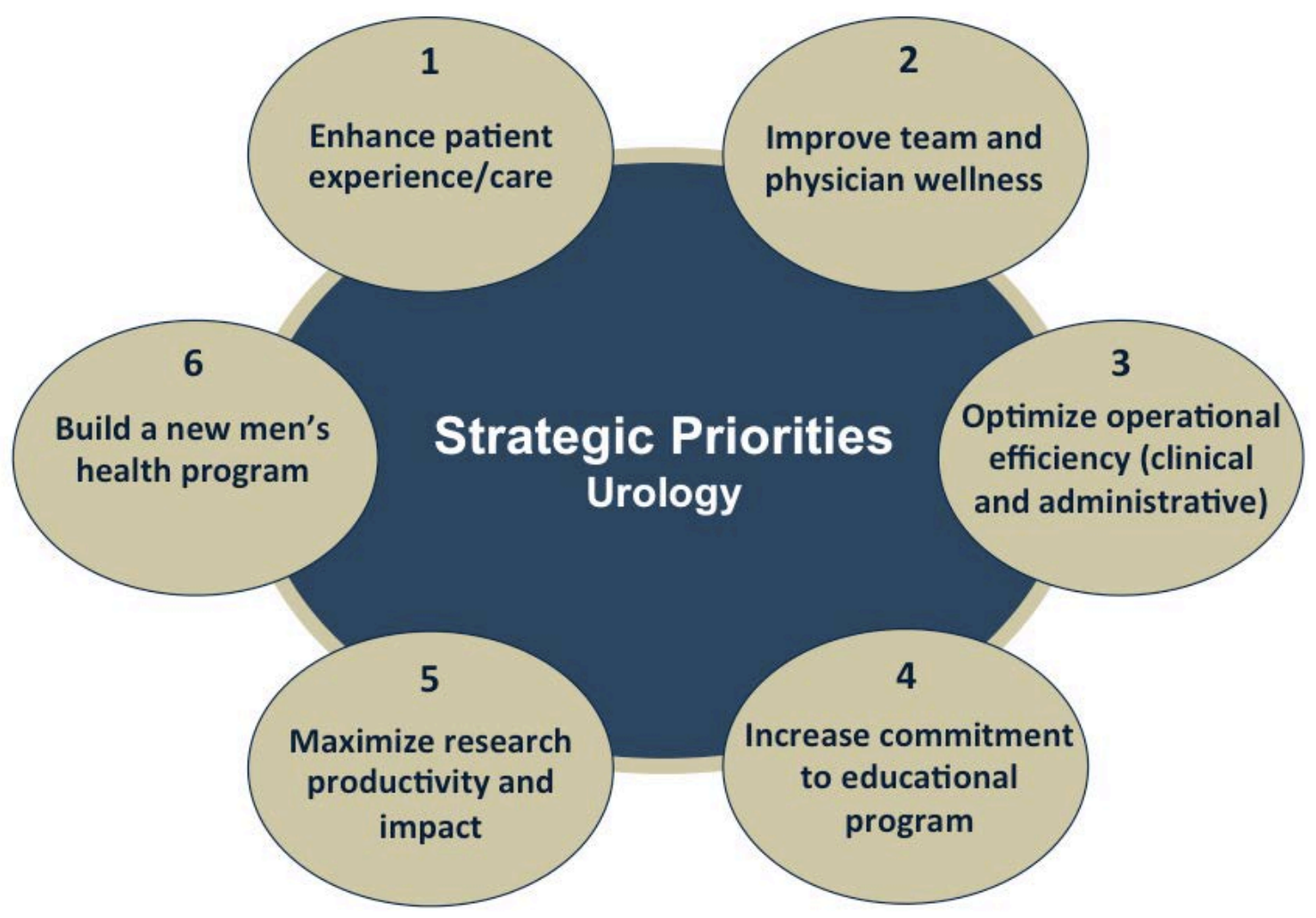


Fig. 5. Kaplan and Norton's balanced scorecard.

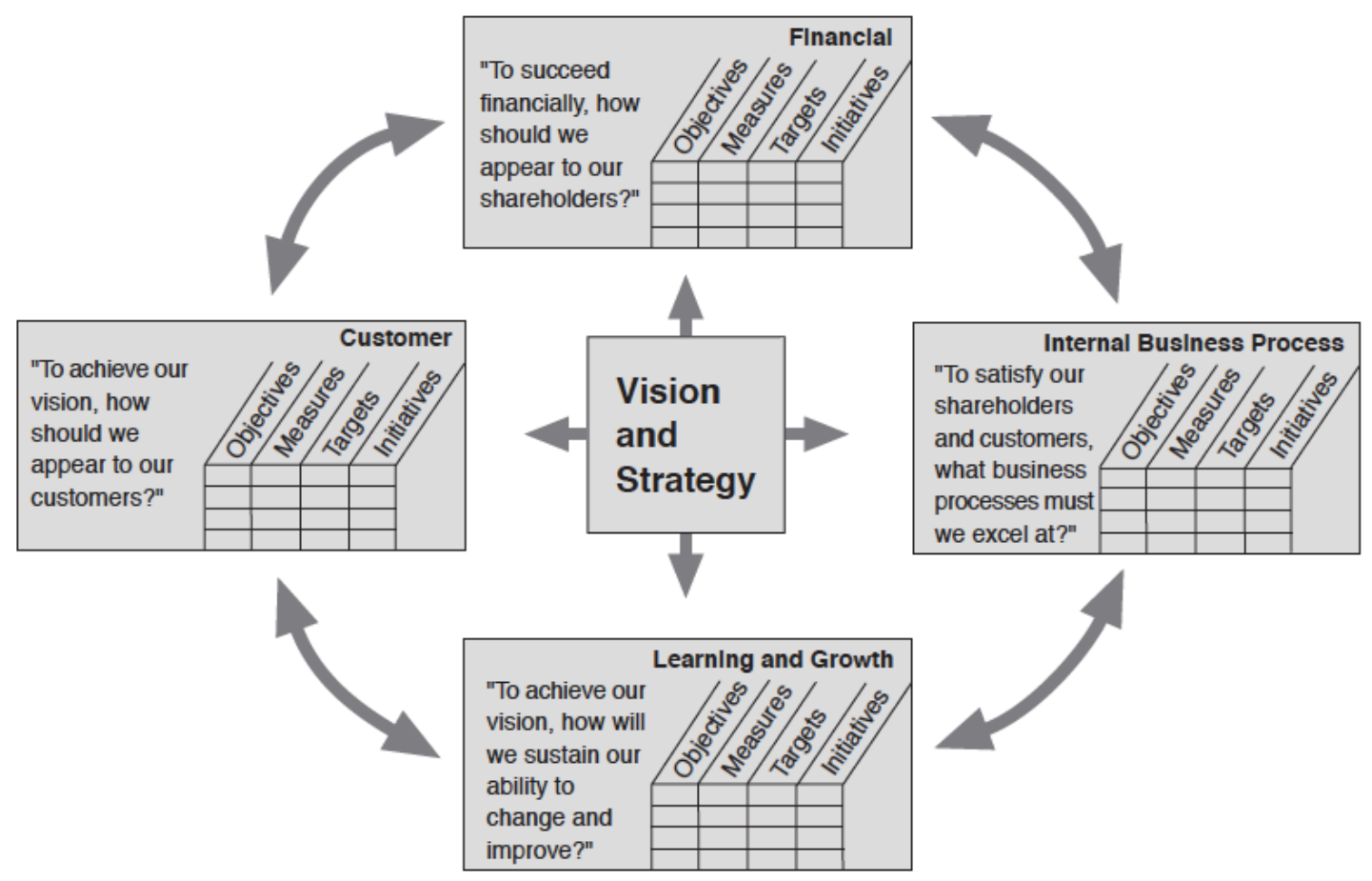


Fig. 6. Sample balanced scorecard for a urology department or division.

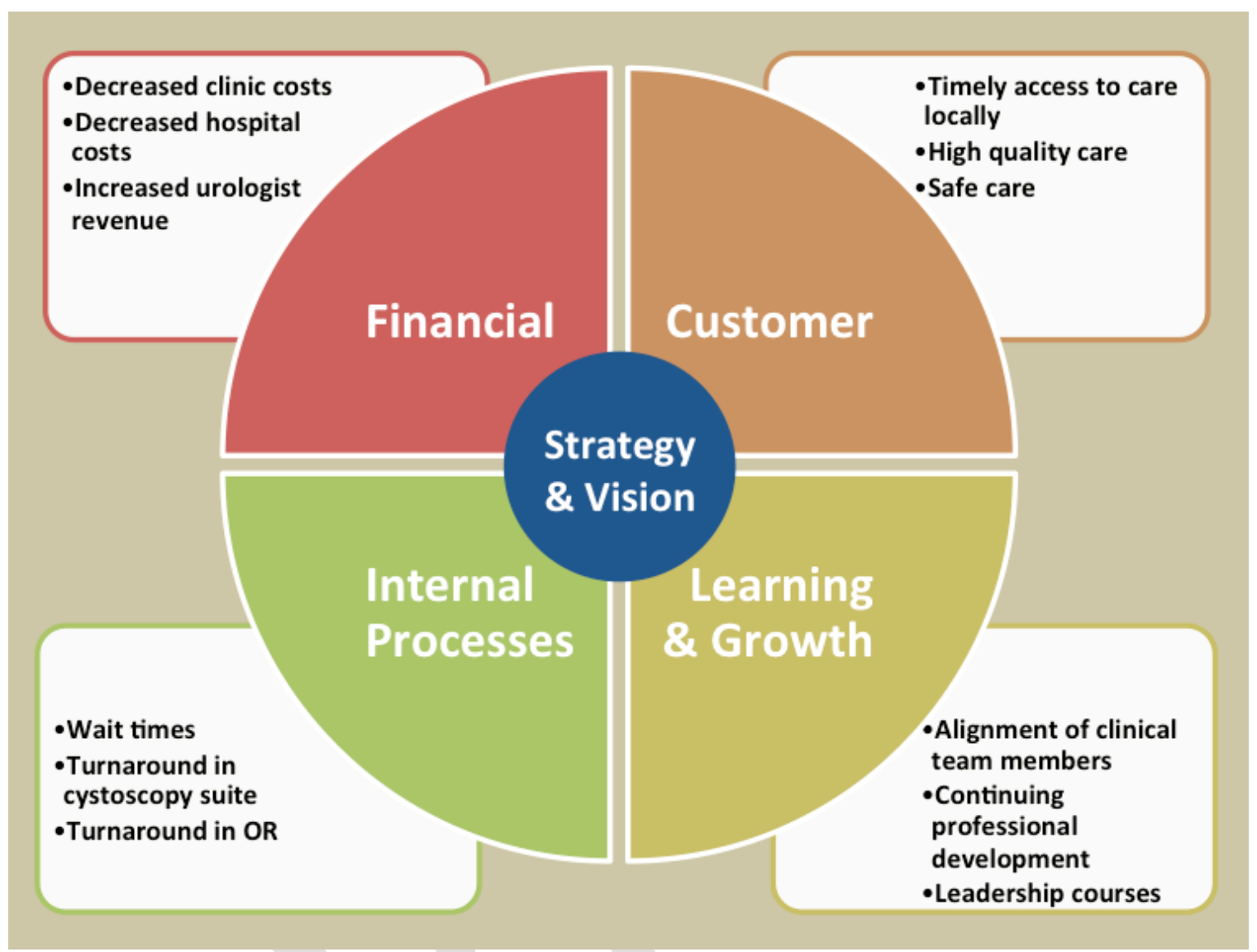


Fig. 7. Sample portion of a strategic map for a urology department or division

\section{Strategic Theme: Operational Efficiency}

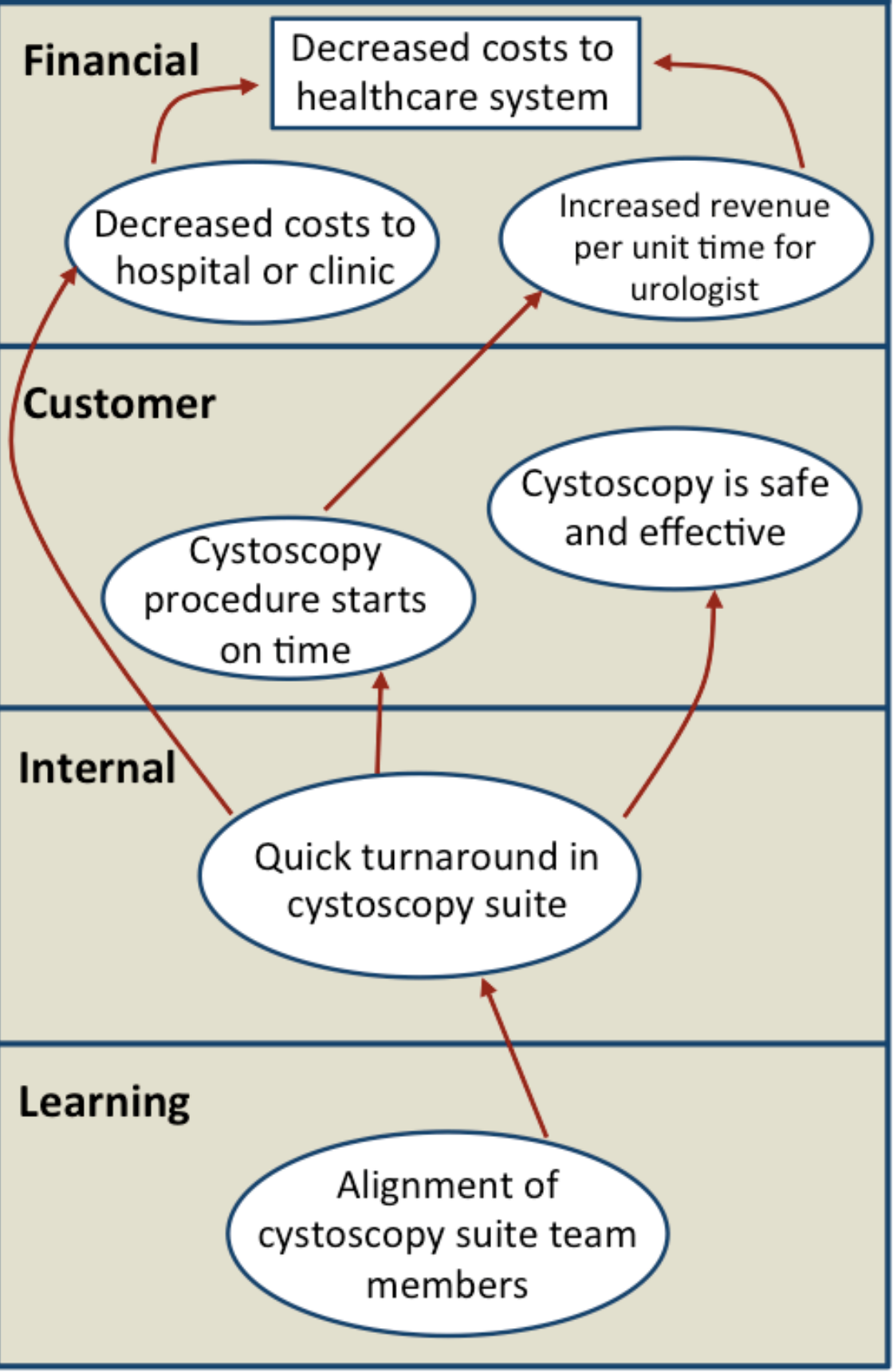




\begin{tabular}{|c|c|c|}
\hline Organization & Mission statement & Vision \\
\hline $\begin{array}{l}\text { American Urological } \\
\text { Association }\end{array}$ & $\begin{array}{l}\text { AUA promotes the highest } \\
\text { standards of urological } \\
\text { clinical care through } \\
\text { education, research and the } \\
\text { formulation of health care } \\
\text { policy. }\end{array}$ & Advancing urology \\
\hline $\begin{array}{l}\text { Royal College of Physicians } \\
\text { and Surgeons of Canada }\end{array}$ & $\begin{array}{l}\text { To improve the health and } \\
\text { care of Canadians by } \\
\text { leading in medical } \\
\text { education, professional } \\
\text { standards, physician } \\
\text { competence and continuous } \\
\text { enhancement of the health } \\
\text { system. }\end{array}$ & $\begin{array}{l}\text { The best health for all. The } \\
\text { best care for all. }\end{array}$ \\
\hline $\begin{array}{l}\text { Canadian Medical } \\
\text { Association }\end{array}$ & $\begin{array}{l}\text { Empowering and caring for } \\
\text { patients }\end{array}$ & $\begin{array}{l}\text { A vibrant profession and a } \\
\text { healthy population }\end{array}$ \\
\hline $\begin{array}{l}\text { Canadian Medical } \\
\text { Protective Association }\end{array}$ & $\begin{array}{l}\text { To protect the professional } \\
\text { integrity of physicians and } \\
\text { promote safe medical care } \\
\text { in Canada }\end{array}$ & $\begin{array}{l}\text { The CMPA is valued as an } \\
\text { essential component of the } \\
\text { Canadian healthcare system }\end{array}$ \\
\hline
\end{tabular}


Table 2. Recommended books on strategy.

\begin{tabular}{|l|l|l|l|}
\hline \multicolumn{1}{|c|}{ BOOK TITLE } & \multicolumn{1}{|c|}{ AUTHOR(S) } & \multicolumn{1}{|c|}{ PUBLISHER } & YEAR \\
\hline Strategic Analysis and Action (9th Ed.) & $\begin{array}{l}\text { M.M. Crossan, } \\
\text { M.J. Rouse, } \\
\text { W.G. Rowe, } \\
\text { C.C. Maurer }\end{array}$ & Pearson Canada & 2016 \\
\hline $\begin{array}{l}\text { Good Strategy Bad Strategy: The } \\
\text { Difference and Why It Matters }\end{array}$ & R. Rumelt & $\begin{array}{l}\text { Crown Publishing } \\
\text { Group }\end{array}$ & 2011 \\
\hline $\begin{array}{l}\text { The Creative Destruction of Medicine: } \\
\text { How the Digital Revolution Will Create } \\
\text { Better Health Care (Reprint Ed.) }\end{array}$ & E. Topol & Basic Books & 2013 \\
\hline $\begin{array}{l}\text { HBR's 10 Must Reads on Strategy } \\
\text { HBR }\end{array}$ & M.E. Porter et al. & $\begin{array}{l}\text { Harvard Business } \\
\text { Review Press }\end{array}$ & 2011 \\
\hline
\end{tabular}

